\title{
EngagedScholarship@CSU
}

Marketing

Browse Business Faculty Books and Publications by Topic

Spring 1973

\section{Market Research in Guided Market Place}

Andrew C. Gross

Cleveland State University, a.gross@csuohio.edu

László Szabó

Hungarian Institute for Market Research

Follow this and additional works at: https://engagedscholarship.csuohio.edu/busmarkt_facpub

Part of the International Business Commons, and the Marketing Commons

How does access to this work benefit you? Let us know!

Publisher's Statement

(c)1973 Emerald

\section{Original Citation}

Gross, A., \& Szabó, L. (1973). Market research in the guided market place. European Journal of Marketing, 7(1), 1-17.

\section{Repository Citation}

Gross, Andrew C. and Szabó, László, "Market Research in Guided Market Place" (1973). Marketing. 33.

https://engagedscholarship.csuohio.edu/busmarkt_facpub/33

This Article is brought to you for free and open access by the Browse Business Faculty Books and Publications by Topic at EngagedScholarship@CSU. It has been accepted for inclusion in Marketing by an authorized administrator of EngagedScholarship@CSU. For more information, please contact library.es@csuohio.edu. 


\title{
MARKET RESEARCH IN GUIDED MARKET PLACE
}

\author{
Andrew C. Gross, Cleveland State University
}

This article was originally published in:

Gross, A., \& Szabó, L. (1973). Market research in the guided market place. European Journal of Marketing, 7(1), 1-17.

Post-print standardized by MSL Academic Endeavors, the imprint of the Michael Schwartz Library at Cleveland State University, 2012

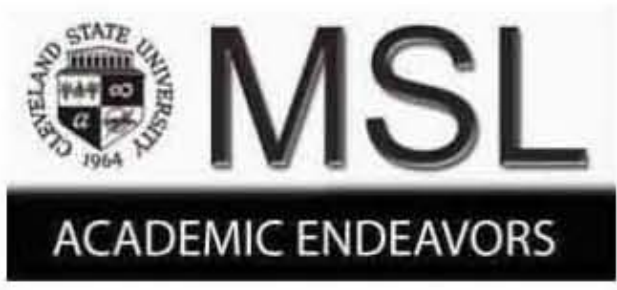




\section{Market research in the guided market place}

\author{
by Andrew Gross \\ Cleveland State University \\ and Låszló Szabó \\ Hungarian Institute for Market Research
}

THE following dates show, in a simplified way, the past record of interest in market research in the socialist countries of Eastern Europe. The Englishlanguage version of Clodwig Kapferer's pioneering volume on market research in Europe was published in 1956 , followed by the German edition in I963. The Hungarian translation did not appear until I969, yet the book reviewer thought that the publication was justified even at that late date [I]. The present situation, that of the I970s, is a very different story. As a result of industrialization, rising incomes and economic reforms, there is a great upsurge of interest in all aspects of marketing in Eastern Europe, including market research theory and practice.

Market intelligence activities in the region are now carried out by scores of enterprises and various research institutes as well as individual scholars and groups at universities. Despite a late start, the production orientation of managers, and the existence of sellers' markets, impressive progress is being made. Research methodology and practices are being adapted as well as redesigned to carry out the "socialist marketing task". Market researchers probe their home markets for both domestic and imported goods. At the same time, neighbouring socialist nations, developed capitalist economies and developing countries are being investigated for their export potentials.

In this article, we focus chiefly on research within and for East European markets, mentioning briefly how export markets are explored. We comment on the role of market research in socialist economies, discuss ways of organizing for market intelligence pursuits, and analyse the growing markets of the region with the aid of case studies. Much of the specific information cited refers to the Hungarian experience under the New Economic Mechanism, although data from other Comecon nations are cited as well.

\section{AN OVERVIEW OF THE LITERATURE, 1971}

Much attention has been paid recently to the markets of and marketing in the socialist countries of Eastern Europe, both within and outside the region. The space devoted to market research has been more limited. Here is a sample of Englishlanguage publications, all from I97I, which illustrate the current range of interest and the depth of investigations. In a brief and breezy article, Ronald Hurst [2] gave practical tips of business etiquette and described briefly the role of foreign trade organizations and trade fairs in the region. His remarks were orientated toward British firms wishing to export; he suggested chambers of commerce and embassies as appropriate starting points for gathering market information. Peter Lauter [3], writing in a US journal, found much consensus on the role of marketing principles, but reported that marketing activities of socialist enterprises are characterized by certain problems and misunderstanding. Yet he found also that institutional arrangements, including those for research, are being developed for a "creative and consistent application of modern marketing".

An in-depth "review of the conceptual approaches to marketing which have been developed within socialist societies" was offered by Gordon Wills and Roy Hayhurst in an earlier issue of this journal [4]. While noting the impact of historical and current political forces, the authors concluded that substantial changes in orientation are taking place, with regard to research, distribution, promotion, and other activities. In the section on market intelligence, the work of Soviet, Polish and Hungarian research institutes was discussed, with brief mentions of information sources and methodology. And most recently, on the pages of this journal [5], Gábor Hoványi, a Hungarian executivelecturer, discussed the legal and socio-economic basis of marketing activities in his country. He described the domestic and foreign challenges facing 


\section{MARKET RESEARCH IN GUIDED MARKET PLACE}

Hungarian enterprises, offered some guidelines on marketing strategies and drew some comparisons between Eastern and Western practices.

The following Hungarian papers, again all from 197I, are illustrative of marketing articles appearing in Eastern Europe. Károly Ravasz [6] discussed the problems facing two major Hungarian manufacturers as they seek to broaden their export markets. Whether to feature the organization or its product line in advertisements and the promotional literature was one of the key questions which had to be resolved in both instances; another problem, also successfully solved, related to the exploration of new markets, East and West. Zoltán Kelemen [7] and István Csüri [8] commented, respectively, on the dimensions of the Hungarian market for new machinery and for passenger cars. The demands of industry and ultimate consumers and the availability of growing supply in both cases signal growing markets for such products.

At a more theoretical level than the above papers, János Kornai [9] discussed the notion of equilibrium and "suction and pressure on the market". This economist, in a far-ranging treatise, explored the facets of sellers' and buyers' markets, noting the trend toward the latter in the socialist countries. In what may well be one of the key articles on the subject, István Gergely [10] analysed the concept of marketing and its socialist application, within a comparative framework. In his view, socialist enterprises subordinate their marketing activities to national interests and social expectations and do not necessarily seek maximum profits at any given time.

Numerous additional examples may be cited from the literature of various countries which deal with marketing principles and practices in socialist countries. Publications of the two authors themselves [II, I2] can also serve as bases for comparison between East and West. Our focus here, however, is narrower: specifically, to describe the function of market research within the socialist marketing task. Based on others' and our own analyses, we see this role in a fourfold way as follows.
THE ROLE OF MARKET RESEARCH IN THE SOCIALIST MARKETING TASK

The first task of market research is to take into consideration the needs and aspirations of society. In doing this, the obvious question is: what are social demands and how are they expressed? To illuminate such a complex topic is beyond the scope of this paper, so let us resort to a specific example. It is quite clear that, much as in other countries, certain small, neighbourhood grocery stores in Budapest are uneconomical and inefficient. But before suggesting the closing of such stores, a market researcher would consider, among other aspects, the shopping habits of the neighbourhood, the availability of private and public transportation, and the food distribution network. The decision may well be to operate the store with state subsidy for several years, re-examining the question when one or more of the basic factors have changed.

A second role for market research is to coordinate state and enterprise planning. In this context, five-year plans serve as indirect and the system of federal regulations as direct guidelines. For a socialist economy of indirect guidance (such as that of Hungary now), this task is especially crucial, because market researchers must interpret broadly defined national objectives for enterprises which now function quite independently [ $\left.\mathrm{I}_{3}\right]$. Consider again a specific example, that of pricing. Table I illustrates types of pricing by major economic sectors in Hungary; within each sector further guidelines are given. (Incidentally, the table also shows the desire to meet social demands, the possibility of price fluctuations being smaller for consumer goods. Not shown is the fact that basic staples, such as bread, are subsidized, while luxury items, such as pastry, are not.) A good company researcher will see his task here in two ways: ( $\mathrm{r}$ ) taking into account macroeconomic guidelines when assessing the market for the products of his organization; and (2) providing feedback to both his enterprise and state authorities, if the guidelines appear to disrupt the market or do not work correctly otherwise.

The third and fourth tasks for market researchers 
TABLE 1: Major product lines vs. type of price systems, the Hungarian economy, 1970

\begin{tabular}{lccc}
\hline \multicolumn{1}{c}{ Price form } & $\begin{array}{c}\text { Basic } \\
\text { or raw } \\
\text { materials }\end{array}$ & $\begin{array}{c}\text { Tndustrial } \\
\text { goods }\end{array}$ & $\begin{array}{c}\text { Con- } \\
\text { sumer } \\
\text { goods }\end{array}$ \\
\hline Fixed prices & $\%$ & $\%$ & $\%$ \\
Maximum price & 30 & 3 & 20 \\
specified & & & \\
Price range specified & 40 & 3 & 30 \\
Free prices & 2 & 78 & 28 \\
Total & 28 & 100 & 100 \\
& 100 & & \\
\hline
\end{tabular}

Note: Trend is toward free prices for consumer goods too; figures for end of $197 \mathrm{I}$ are $18,3 \mathrm{I}, 23$, and $28 \%$, respectively. Source: Gergely, István, "Planning Information Basis of Marketing Activity", Marketing-Piackutatás, Third Quarter, 1971, p. 265 .

are those which we normally associate with their activities: the observation of events occurring in the marketplace and the subsequent analysis of these events. The former involves gathering information from a great variety of sources via primary and secondary research; the latter means seeking explanations, evaluations and implications. In carrying out both functions, researchers must be aware of the fact that the dimensions of a socialist marketplace, as well as marketing activities within it, differ from those of capitalist markets. Thus, in socialist markets, even those of indirectly guided economies, there is less freedom, certainly for enterprises, as Hoványi noted [5]. Trade fairs receive a greater role, direct mail and advertising a significantly lesser role than is the case in certain Western economies. Research methods themselves need not differ, but as a result of the above they will be used in a "different" mix, eg visitors at fairs and consumer panels are much more frequently utilized than readership or audience surveys.

\section{ORGANIZING FOR MARKET INTELLIGENCE ACTIVITY}

In this section, with special reference to Hungary, we first explore the extent to which market research activities are carried out by enterprises in Eastern
Europe. Next, comments are made on the activities of autonomous institutes and university task forces. Finally, the way in which firms from socialist, capitalist and developing countries can explore a given East European market is described.

It is over four years now since marketing and market research received "full status" under the aegis of the New Economic Mechanism in Hungary. A representative sample of industrial firms belonging to the Hungarian Chamber of Commerce was surveyed in 1972 to ascertain the extent to which such enterprises are engaged in market research. Among the 187 organizations, $30 \%$ have independent market research sections, $50 \%$ perform such activities within other departments and $20 \%$ do no investigation of markets at all. Among those carrying out research activities, one- to two-man sections exist in 40, three- to five- in 40 , and over six-person sections in $20 \%$ of the cases. About one half of the researchers possess a college or university degree. Market research is said to be in its infancy in many firms, eg among certain heavy machinery, chemical, clothing, and household goods manufacturers, where sellers' markets still exist. Yet if we draw a comparison between the specific market research activities of US and Hungarian companies, as Table 2 does, taking into account the later start and the different orientation of the Hungarians, then the situation is remarkably similar. Foreign trade organizations in the other socialist countries of Eastern Europe are equally keen in exploring export markets, while enterprises oriented toward domestic trade are being prodded in the same direction under the pressure of economic reforms, the appearance of imports and sophisticated buyers.

Market research in Eastern Europe has a longer history in government and independent institutes than in enterprises or co-operatives. Because of the major role of foreign trade in the Comecon countries [5], economic and market research institutes were first established in ministries of foreign trade. Domestic markets were considered less important, although experimentations and investigations were made in the 1950 os in Yugoslavia, Poland, Hungary and Czechoslovakia. Economic development and 


\section{MARKET RESEARCH IN GUIDED MARKET PLACE}

TABLE 2: Market research activities of US and Hungarian enterprises, 1963 and 1971

\begin{tabular}{|c|c|c|c|c|c|}
\hline \multirow[b]{2}{*}{ Type of activity } & \multicolumn{5}{|c|}{ Percent of companies performing that activity } \\
\hline & at all & $\begin{array}{l}\text { USA I963 } \\
\text { within } \\
\text { market } \\
\text { research } \\
\text { depart- } \\
\text { ments }\end{array}$ & all & $\begin{array}{l}\text { Hungar } \\
\text { foreign } \\
\text { trading } \\
\text { organiza- } \\
\text { tions for } \\
\text { foreign } \\
\text { markets } \\
\text { only }\end{array}$ & $\begin{array}{l}\text { I97I } \\
\text { domestic } \\
\text { enter- } \\
\text { prises } \\
\text { for } \\
\text { domestic } \\
\text { markets } \\
\text { only }\end{array}$ \\
\hline \multirow{7}{*}{$\begin{array}{l}\text { 1) Market characteristics and } \\
\text { market potentials } \\
\text { 2) Market share analysis, } \\
\text { competitive products } \\
\text { 3) Business trend, business cycles } \\
\text { 4) Forecasting, short and long run } \\
\text { 5) Price, profit and value analysis } \\
\text { 6) Advertising effectiveness } \\
\text { Number of companies }\end{array}$} & $6_{7}-68$ & 62 & $6 I-60$ & So & $8 \mathrm{r}$ \\
\hline & $65-67$ & & $50-58$ & 76 & 68 \\
\hline & 58 & $\begin{array}{c}53^{-01} \\
47\end{array}$ & $30-36$ & 68 & 37 \\
\hline & $59-62$ & $4^{6}-48$ & $27-33$ & 40 & 38 \\
\hline & 53 & 21 & $49^{-54}$ & 80 & 68 \\
\hline & $4^{8}$ & 25 & $5^{-19}$ & 12 & 23 \\
\hline & 1660 & 1660 & 187 & 27 & 93 \\
\hline
\end{tabular}

reforms in the 1960 s led to the establishment of market research institutes whose primary concern has been the domestic marketplace. Organizations of this type have been in operation now for more than ten years in Belgrade and Zagreb as well as in Prague. The work of the Hungarian Institute for Market Research and similar institutes has been well summarized in the articles of Lauter [3], Wills and Hayhurst [4] and Hoványi [5]. It should be noted that, almost without exception, autonomous market research institutes orientated toward domestic markets function without state subsidies; their growth is dependent on commissioned work from domestic and foreign clients.

The picture would not be complete if we did not mention the market research activities of (I) radio and television agencies and (2) university task forces. Several East European broadcasting organizations maintain public opinion polling facilities. While information gathering is usually focused on public issues, consumer goods preference surveys are also conducted from time to time. At the university level, adjoining appropriate departments, market research groups or business research bureaux function and especially flourish in Poland, Hungary and Yugoslavia. As one example, the market research group at the Karl Marx University of Economics in Budapest has undertaken recently a major survey for a group of furniture manufacturers. Students are utilized in both the actual household interviews and in the processing of questionnaires, but work under the supervision of professors, many of whom have visited East and West European as well as US industrial enterprises and graduate schools of business.

It would be incorrect to claim that Western methods can be adapted without change in Eastern markets. Indeed, market research techniques relevant in one of the socialist countries may be inapplicable in another, due to differences in the structure of the economy, the status of economic reforms, managerial principles and legal restrictions. Within the Comecon area, on the basis of longrange bilateral agreements and the principle of reciprocity, information is exchanged usually between foreign trade organizations and sometimes 


\section{MARKET RESEARCH IN GUIDED MARKET PLACE}

between individual manufacturers. In addition, individuals on exchange programmes and a large number of conferences facilitate the exchange of ideas and materials. But, as a recent article by one of us shows conclusively, there is much room for improvement [II]. Industrial enterprises of one country lack information about the competitive environment of partner countries and about the extent to which the needs of households and producers are being met. Yet case studies show that primary market information can be obtained through co-operation among autonomous institutes or agencies within the Comecon area.

Developing and Western countries can and do commission market surveys in Eastern Europe. In Hungary, Czechoslovakia and Yugoslavia contracts can be signed directly with one of the autonomous institutes; in the other countries the surveys must be contracted indirectly through another state agency. One of the most comprehensive and useful volumes on this and related topics is Exporting to the Socialist Countries of Eastern Europe-A Guide to Marketing Techniques [15]. Published by the International

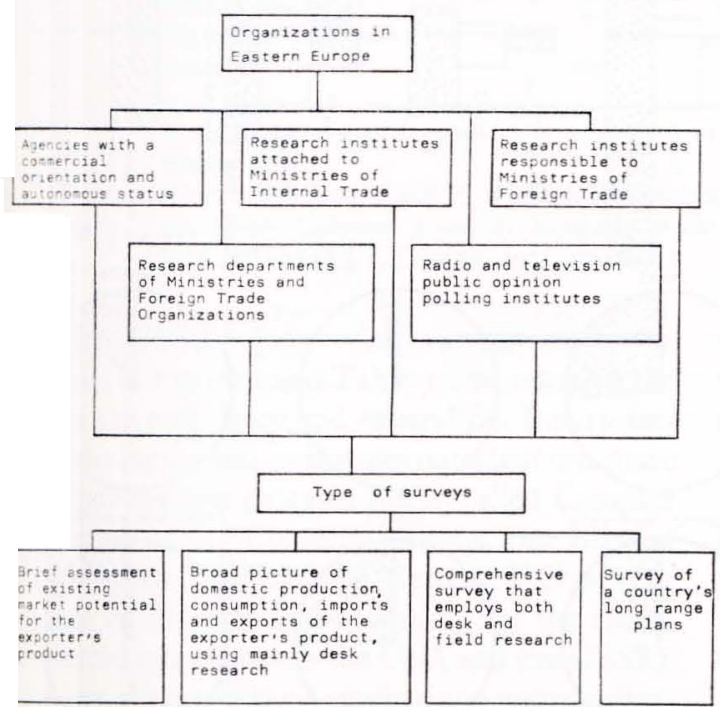

Trade Centre of UNCTAD-GATT in Geneva last year, this text offers a wealth of information (400 pages, 40 appendices, 300-item bibliography) on both marketing and market research. Written primarily for businessmen and state officials of the developing countries, the volume can be utilized to great advantage by marketeers and market researchers in the developed countries as well. Figure I, based on the text of one chapter, summarizes the types of surveys and the types of research organizations in Eastern Europe. The ITC volume, in addition, describes time and cost considerations and offers a comparative evaluation of having market research performed by East European institutes as against commercial agencies outside the region [15].

It seems clear that any company or enterprise, whether from a socialist, capitalist or developing country, cannot and need not limit its market survey to desk research findings about, or short, personal visits to, Eastern Europe. Institutes and agencies within, or outside, the region stand ready to assist the would-be seller in measuring the pulse of the market and the potential for his product line. The

Figure I: Market research organizations and surveys for Eastern Europe from the viempoint of exporters in the developing and Western countries

Source: Exporting to the Socialist Countries of Eastern Europe, Geneva: ITC-UNCTAD-GATT, 1971, p. 123 as amended. 
accepted practice at the Hungarian Institute for Market Research, as well as at some other Eastern and Western agencies, is to recommend and carry out a pilot study. In addition to a summary of available relevant statistics, such a study can include a survey of representative households or purchasing agents and, if desired, certain market tests. Only if the results are affirmative will a more extensive research programme (on distribution, promotion, etc) and actual marketing activities be recommended.

\section{GROWING MARKETS AND \\ DISCRIMINATING BUYERS}

Over the past three decades the socialist countries of Eastern Europe transformed themselves from predominantly agricultural economies into industrial ones. As industrializing economies they exhibit high growth rates, in excess of those in Western Europe or North America. Possessing 10\% of the world's population, the region now accounts for about $30 \%$ of industrial production and $12 \%$ of foreign trade in the world [16]. In the current decade, population is expected to rise at the rate of I \% per year to reach 400 million persons, while gross national product will rise to 1000 billion constant ( 1967 ) dollars by 1980 [17]. The USSR is, of course, by far the largest market, but "the greater dependence of the others on foreign trade make them of equal interest to the foreign exporter ... the six smaller markets import some $50 \%$ more

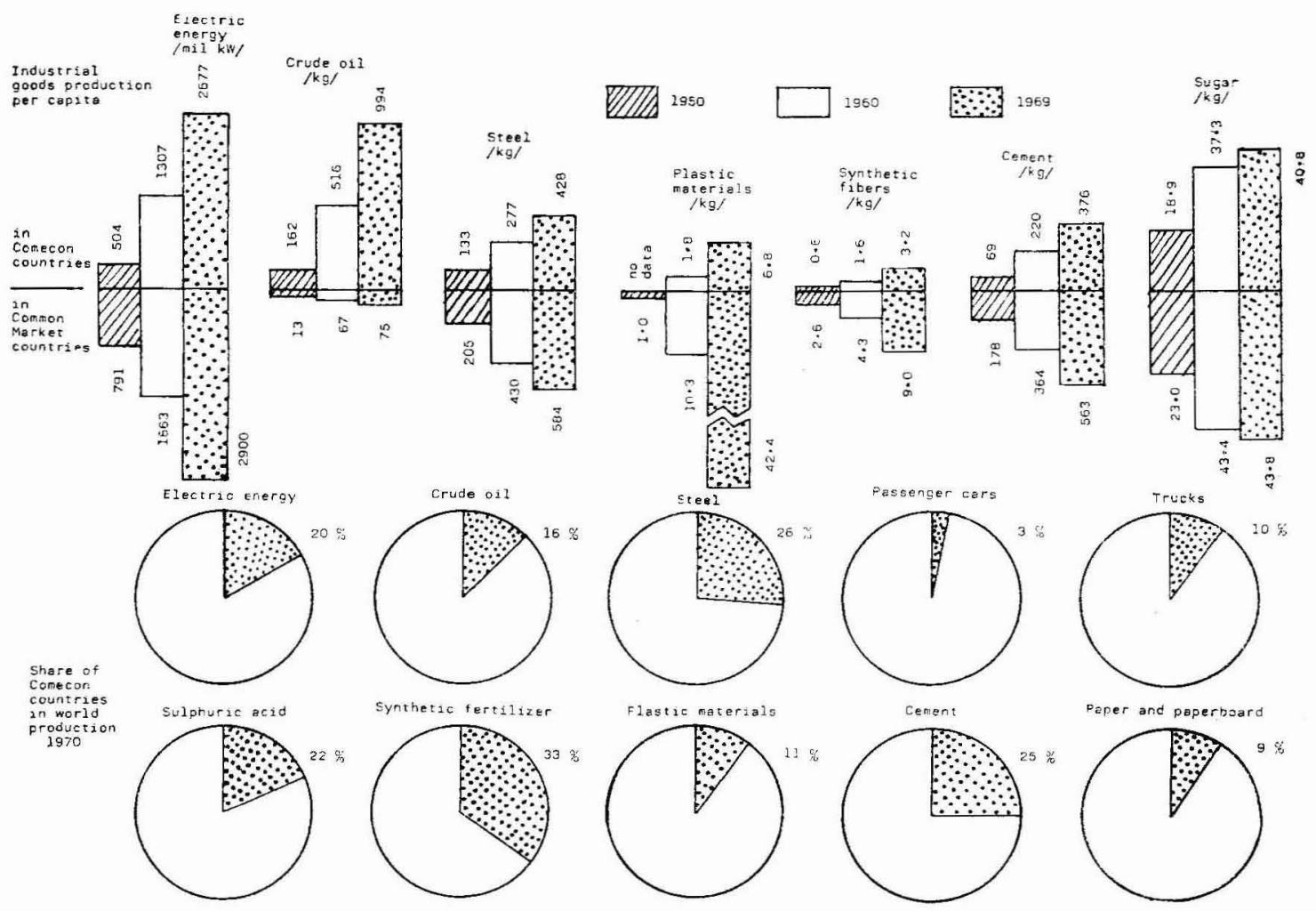

Figure 2: Selected important industrial goods production, Comecon and Common Market areas, I950-69 Source: The Complex Programme of The Comecon Countries, Budapest, Kossuth Könyvkiadó, 1971. 
TABLE 3: Data and forecasts for selected economic indicators East European countries, 1965-1980

\begin{tabular}{|c|c|c|c|c|}
\hline \multirow[t]{2}{*}{ Country } & $\begin{array}{l}\quad P \\
\text { gross na } \\
\text { actual } \\
\text { value } \\
\text { 1970 } \\
\text { (dollars, } \\
\text { 1967 } \\
\text { value) }\end{array}$ & $\begin{array}{l}\text { ta } \\
\text { product } \\
\text { average } \\
\text { annual } \\
\text { growth } \\
\text { rate, } \\
\text { I970-80 }\end{array}$ & $\begin{array}{l}\quad \text { Per } \\
\text { gross dome } \\
\text { actual } \\
\text { value } \\
\text { I965 } \\
\text { (dollars, } \\
\text { I963 } \\
\text { value } \\
\text { except as } \\
\text { noted) }\end{array}$ & $\begin{array}{l}\text { pa } \\
\text { product } \\
\text { average } \\
\text { annual } \\
\text { growth } \\
\text { rate, } \\
\text { 1970-80 }\end{array}$ \\
\hline & $\$$ & $\%$ & & $\%$ \\
\hline Bulgaria & II 88 & $4 \cdot 6$ & 3035 leva & $7 \cdot 0$ \\
\hline $\begin{array}{l}\text { Czechoslovakia } \\
\text { German Democratic }\end{array}$ & I998 & $3 \cdot 7$ & $\$ 1240$ & $4 \cdot 4$ \\
\hline Republic & 2035 & $3 \cdot 7$ & I348 & $4 \cdot 8$ \\
\hline Hungary & 1433 & $4 \cdot 6$ & 870 & 5.0 \\
\hline Poland & 1292 & $4 \cdot 2$ & 870 & 49 \\
\hline Romania & 1069 & $4 \cdot 8$ & 627 & 6.9 \\
\hline USSR & 1863 & $3 \cdot 9$ & 969 & $5^{-8}$ \\
\hline $\begin{array}{l}\text { Yugoslavia } \\
\text { Six East European }\end{array}$ & 492 & 7.0 & n.a. & n.a. \\
\hline $\begin{array}{l}\text { countries } \\
\text { (excl. USSR and } \\
\text { Yugoslavia) }\end{array}$ & n.a. & n.a. & n.a. & $5 \cdot 3$ \\
\hline $\begin{array}{l}\text { Seven East European } \\
\text { countries } \\
\text { (excl. Yugoslavia) } \\
\text { Eight East European }\end{array}$ & n.a. & n.a. & n.a. & $5 \cdot 7$ \\
\hline countries & 1677 & $4 \cdot 0$ & n.a. & n.a. \\
\hline
\end{tabular}

Note: Gross domestic product is equivalent to the output of goods and services valued at market prices.

Source: Columns I and 2: Worldcasts, $R-2$, August, 1971 , Predicasts, Inc., Cleveland, $197 \mathrm{I}$, pp. 18-26. Columns 3 and 4 : Exporting to the Socialist Countries of Eastern Europe, ITCUNCTAD-GATT, Geneva, I97I, pp. 258-9.

than the USSR" [15]. The various economic indicators in Figure 2 and Table 3 illustrate that the markets are both large and expanding. Enterprises within the region and companies outside it are aware of the implications (witness the so-called Complex Programme of the Comecon nations, the growing trade between Western and Eastern Europe, the presence of Third World products, and the recent commercial talks between the USA and the USSR).

Known always for their emphasis on industrialization and industrial goods, the socialist countries of Eastern Europe are approaching the consumer era. It would be incorrect to state that machinery and equipment production are no longer emphasized, eg, several countries in the region put $30 \%$ of their gross national products into capital investment. If we examine foreign trade by commodity groups in the various countries in recent years, we find that in both exports and imports the growth rates for machinery and equipment were similar to those for manufactured consumer goods $[15,16]$. Ships, tractors and buses are among the hundreds of items exported; machine tools, computers and materialhandling equipment represent just a few of the many imported heavy goods. Spring trade fairs, such as those in Brno, Budapest and Leipzig, continue to 


\section{MARKET RESEARCH IN GUIDED MARKET PLACE}

feature domestic and foreign machinery, and often represent both market research and marketing opportunities.

In the post World War II era, but especially since 1965, consumer goods are receiving added emphasis in Eastern Europe. This is a result of several underlying trends: an equalization process in occupational incomes, a rise in per capita incomes, and the recognition of legitimate consumer needs as expressed in political and economic reforms. There is a trend toward equalization in the regional distributions of income too, between cities and villages in a given country and among the Comecon nations $[18,19]$. Certain universal trends, such as the increased participation of women in the labour force and the growth in leisure time, have created demands for convenience foods, camping equipment and other goods. Finally, the process of mass communications coupled with advertising (though still to a limited extent) have further whetted the appetite of consumers for "non-necessity" items.

The following few statistics give a flavour of the increase in the number and variety of goods available to Hungarian households. Sales of electric refrigerators rose from 13000 in 1960 to 191000 in 1969 , while the number of television receivers sold in those two years was 53000 and 215000 , respectively [20, 2I]. The number of different detergents and soaking liquids available increased from 12 in I 962 to 39 by 1972 . Váci utca, a major pedestrian shopping mall in the heart of Budapest, features a dazzling variety of domestic and foreign goods. In the USSR, the number of television sets per 1000 persons jumped from 22 to 96 between I 960 and 1967 ; the corresponding figures for washing machines went from 13 to 89 , refrigerators from 10 to 47 , vacuum cleaners from 8 to 22 and sewing machines from 107 to ${ }_{15}$ [22]. Similar statistics could be cited for the other Comecon nations and for Yugoslavia.

As is true for capital equipment, the growth in consumer goods in the region does not necessarily imply a ready-made market for exporters from the capitalist, developing or even the other socialist countries. In fact, due to expanding trade and economic reforms, competition has become more intense. Today, Asian, African and European products can be found side by side on supermarket shelves in Eastern Europe, though admittedly, the choice is not as great as in Western Europe. With the aid of market research and subsequent appropriate marketing activities, featuring a good product, arranging for distribution, undertaking promotion, it is possible to enter and remain in these markets. Certainly, recent trends are encouraging. Consumer goods as a percentage of all imports in Hungary rose from $6.9 \%$ in 1966 to $10.1 \%$ by 1970 . Hungarian retail trade as a whole increased by $46 \%$ between I 967 and 1971 compared to a rise of $22 \%$ in industrial output [23].

Since the advent of economic reforms in Hungary, several consumer information services have developed; generally complementary to each other, together they perform an educational and informational function [24]. First, there is the Forum of Outstanding Products, to which domestic and manufacturers can submit their goods voluntarily, for judgement by experts. Of 1813 items submitted in the past five years, 818 , or $43 \%$, received permission to use the coveted emblem. Second, under the aegis of the Quality Control Institute of the Ministry of Commerce, comparative product tests are performed, with items rated against each other within a given group on durability, packaging, etc. Results are reported on television, the columns of the largest daily paper and Nagyito, the monthly consumers' journal. Third, an intensive campaign is being waged to convince manufacturers to give more and better information on labels and tags attached to their products. Fourth, there are plans to assign consumer advisers to major stores and even open advisory bureaux which would assist potential buyers prior to their purchases. Last but not least, the press frequently carries detailed articles about the variety of goods available, or unavailable, in the stores, along with specific customer complaints about quality.

Consumer information services represent an opportunity for producers to convince potential buyers about the quality of their output; public 


\section{MARKET RESEARCH IN GUIDED MARKET PLACE}

(pinion and panel surveys are the other side of the coin, a chance to obtain feedback from satisfied and unsatisfied purchasers. The Hungarian Institute for Market Research (HIMR) has pioneered in the collection of opinions from both representative households across the nation and from other samples of individuals.

Opinions have been solicited about specific products, vacation plans, credit services, selfvervice shops and so on. Since the 3000 households included in the surveys of the HIMR represent a true cross-section of the nation, and since corresponding objective data are available in some cases, interesting comprisons can be drawn. For example, a 1970 survey revealed that the buying public reacts rather accurately to price increases on different products. The price index for clothing and textile goods increased much more than that for foodstuffs in 1969 (about $2.8 \mathrm{vs} .0 .4 \%$ ) and $80 \%$ of the households thought that the cost of clothing has been rising, as against $48 \%$ saying the same about food items [25]. Naturally, there are differences regarding the same product line by occupation, size of family and location. Accordingly, marketeers can judge the differential impact of price increases by type of goods and within that category by selected demographic variables.

Since the Hoványi article, which appeared in the pages of this journal [5], presented factual data relating to the food trade and self-service shops in

TABLE 4: Public opinion survey results about self-service stores by type of store, Hungary, 1970

\begin{tabular}{|c|c|c|c|}
\hline \multirow[b]{2}{*}{ Item } & \multicolumn{3}{|c|}{$\begin{array}{l}\text { Per cent of houscholds buying self- } \\
\text { service by type of store }\end{array}$} \\
\hline & $\begin{array}{l}\text { Food- } \\
\text { stuffs }\end{array}$ & Clothing & $\begin{array}{c}\text { Manu- } \\
\text { factured } \\
\text { consumer } \\
\text { goods }\end{array}$ \\
\hline \multicolumn{4}{|l|}{ By location } \\
\hline Budapest & 93 & 27 & 56 \\
\hline other major cities & 85 & 28 & 43 \\
\hline villages & 70 & 23 & 29 \\
\hline \multicolumn{4}{|l|}{ By income } \\
\hline $\begin{array}{l}\text { low income (below } 800 \mathrm{ft} / \text { month } \\
\text { per person) } \\
\text { middle income }(800-1400 \mathrm{ft} / \text { month }\end{array}$ & 68 & 25 & 30 \\
\hline $\begin{array}{l}\text { per person) } \\
\text { high income (over } 1400 \mathrm{ft} / \text { month }\end{array}$ & 78 & 24 & 36 \\
\hline per person) & 86 & 26 & 46 \\
\hline Nationwide & 78 & 25 & 38 \\
\hline \multicolumn{4}{|l|}{ Opinion about supply and selection } \\
\hline Better than traditional store & 73 & $3 \mathrm{I}$ & 40 \\
\hline Same as traditional store & 22 & 39 & 34 \\
\hline Worse than traditional store & 2 & 7 & 5 \\
\hline No response & 3 & 23 & $2 \mathrm{I}$ \\
\hline Total & 100 & 100 & 100 \\
\hline \multicolumn{4}{|l|}{$\begin{array}{l}\text { Reasons why supply and selection is } \\
\text { held better }\end{array}$} \\
\hline Better, broader choice of goods & 38 & 14 & 16 \\
\hline Can choose freely & Io & I5 & - \\
\hline Ease of selection & 8 & 4 & 5 \\
\hline Freshness of goods & 7 & - & - \\
\hline
\end{tabular}

Source: Self-Service Shops in the Mirror of Public Opinion, Hungarian Institute for Market Research, Budapest, 1971 . 


\section{MARKET RESEARCH IN GUIDED MARKET PLACE}

Hungary, we thought it might be interesting to supplement that with information based on public opinion surveys. Table 4 summarizes the reaction of the Hungarian buying public to the idea of selfservice in various types of stores. It is obviously better accepted in food stores, more and more of which are going the supermarket way, than in clothing or miscellaneous household goods stores. Advantages of self-service are mentioned by $91 \%$ of households, while only $53 \%$ refer to one or more disadvantages. Results are also available by location, income groups, etc, thereby providing retail management with information on where self-service shops would meet with most acceptance.

\section{ANALYSIS OF MARKETS : SOURCES, METHODS AND CASES}

Sources of market data about Eastern Europe are too many and too varied for detailed discussion here; our remarks will be restricted to a brief overview and to advice regarding utilization of some of these sources. Similarly, there is a vast body of literature dealing with market research methods, most of them common to both East and West; thus, we deal only with some techniques particular to socialist economies [26]. Finally, specific case studies are cited, with particular reference to Hungary which illustrate the range of market research undertaken.

\section{Sources}

Figure I illustrated the way in which market intelligence activity and primary data collection may be undertaken in Eastern Europe. Figure 3, also based on material from the International Trade Centre volume, gives an overview of both the secondary market data needed for research and the various sources where such information may be found. The ITC volume provides discussion on each source, enumerates relevant agencies and organizations, and offers lists of statistical, non-statistical and other sources of published market data in a long bibliography. While the classification shown in the diagram applies to all seven markets in the Comecon area, "the ease with which the data for each category can be obtained and the degree of accuracy and detail, vary considerably from one country to another" [ $\left.\mathrm{r}_{5}\right]$.

What are some of the peculiar characteristics of East European market data? Probably the most important aspect is the publication of five-year plans and within that the specifying of priorities, annual plans and detailed targets. Together, they provide valuable guidelines for the market researcher and marketeer, although one has to check the annual revisions and updating of the long-range plans. Current progress reports are best obtained in the general and industrial press; especially recommended are the largest daily newspapers and the weekly political-economic journals in each country (Népszabadság and Figyelö, respectively, in Hungary). The technical literature, catalogues of major trade fairs, press releases and certain academic publications also constitute valuable sources of market information. Plans of sister states are published in the other Comecon Countries and a variety of trade and technical reviews appear in world languages, eg Marketing in Hungary and Hungarian Exporter, designed expressly for foreign businessmen. Particular advantages of East European sources are as follows: the compulsory statistical reporting service coupled with public control of most enterprises produces detailed economic phenomena; interviews or press releases given by officials who hold several posts (eg industrial executive, party member, adjunct professor) provide more reliable insights; and the existence of the Comecon provides some comparable statistics on seven distinct markets.

There are, of course, some difficulties with market information originating in Eastern Europe, especially for a Western, but even for an Eastern observer. First, there is the language problem, but this can be overcome in a variety of ways, ranging from multilingual analysis to utilizing Comecon and international statistical yearbooks. Second, each nation has its own set of statistics which go beyond and are often not comparable to the combined Comecon statistics. Furthermore, the Comecon system of industrial classification differs consider- 


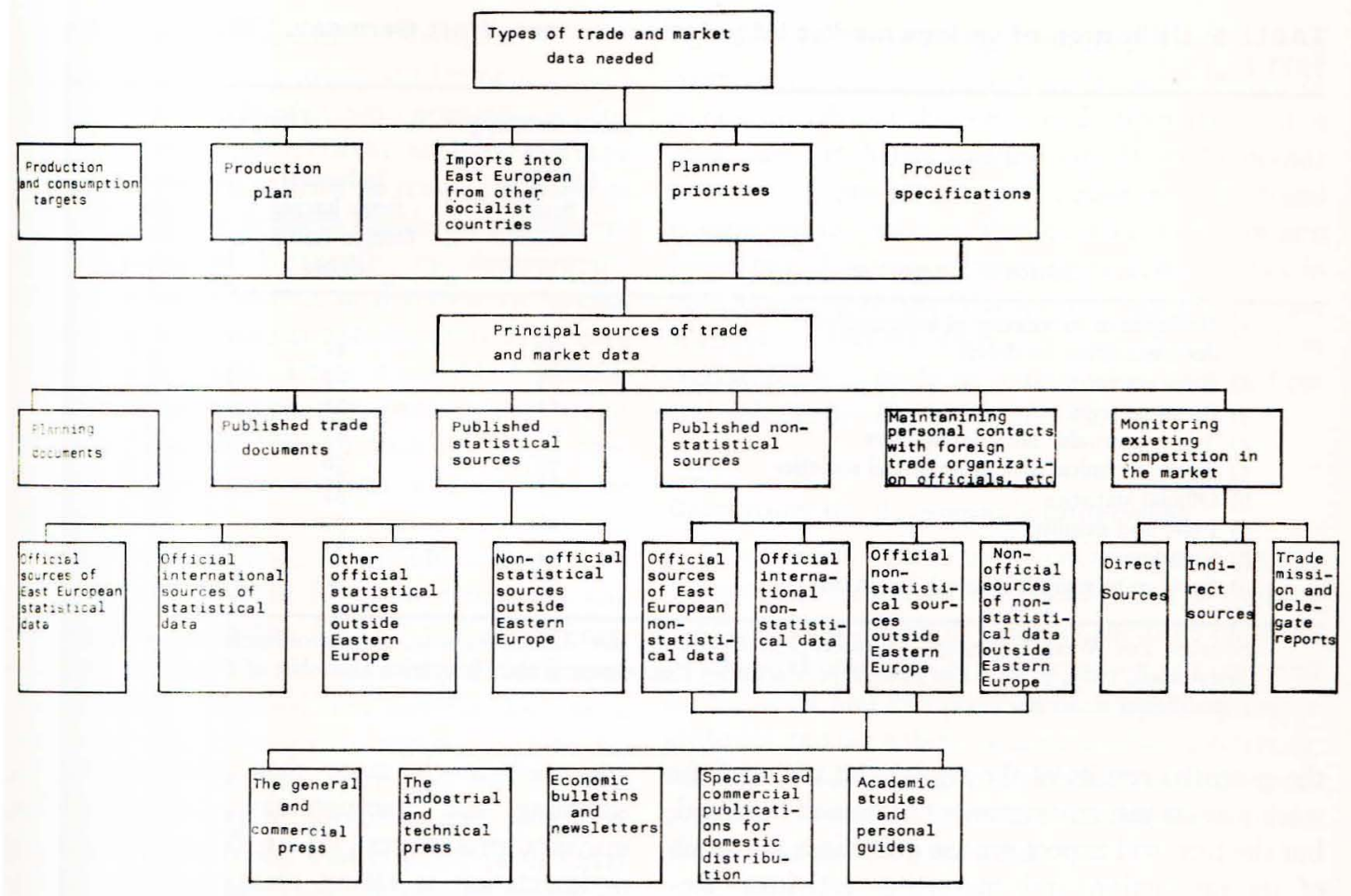

Figure 3: Types of market data needed and sources of market data for Eastern Europe from the viewpoint of exporters in the developing and Western countries

Source: Exporting to the Socialist Countries of Eastern Europe, Geneva: ITC-UNCTAD-GATT, 1971, p. 95.

ably from the Western or United Nations system (Standard Industrial Trade Classification); but some preliminary keys between the two systems are now available. Yet another problem is the restructuring of the various sectors of socialist economies both in the post-war period and again in the 1960 s. As a result, time series are either unavailable or not comparable; it is recommended that one use only the latest yearbooks.

\section{Methods}

Some claim that the level of sophistication in market research techniques in Eastern Europe is very high, others that it is still in its infancy. The truth may well be in between; but what is more important is that certain basic methods and statis- tical procedures are widely known, while others are being adapted to the special circumstances of the region. Several well-established methodological journals in the region aid market researchers in their tasks, eg Marketing-Piackutatás (Hungary), Marketing (Yugoslavia) and Marketing (Czechoslovakia). New techniques are seldom formulated, but each procedure may be given a different emphasis. Let us now consider this matter in terms of undertaking the work, gathering the data, processing the information and analysing the results. Our hypothetical example will be that of a socialist industrial enterprise, such as a manufacturer, giving a commission to an autonomous institute to conduct a domestic market study.

In commissioning the research, the industrial firm has high, often unrealistic, expectations about 


\section{MARKET RESEARCH IN GUIDED MARKET PLACE}

TABLE 5: Utilization of various market information sources, West Germany, 1962 and Hungary, $1971(\%)$

\begin{tabular}{|c|c|c|c|}
\hline \multirow[b]{2}{*}{ Source of information } & \multirow{2}{*}{$\begin{array}{c}\text { West Germany } \\
\text { I } 962 \\
\text { Industrial } \\
\text { firms }\end{array}$} & \multicolumn{2}{|c|}{ Hungary $197 \mathrm{I}$} \\
\hline & & $\begin{array}{c}\text { Industrial } \\
\text { firms having } \\
\text { foreign trading } \\
\text { rights }\end{array}$ & $\begin{array}{c}\text { Industrial } \\
\text { firms not } \\
\text { having foreign } \\
\text { trading rights }\end{array}$ \\
\hline $\begin{array}{l}\text { I) Bulletins or newsletter of information- } \\
\text { documentation institutes }\end{array}$ & 90 & 42 & 36 \\
\hline 2) Sales statistics & 85 & 67 & 71 \\
\hline 3) Business trips & $8 \mathrm{r}$ & $7 \mathrm{I}$ & 56 \\
\hline 4) Trade journals, daily newspapers & 80 & 83 & 84 \\
\hline 5) Trade technical and professional societies & 79 & 38 & 35 \\
\hline 6) Official statistics & $6 \mathbf{I}$ & 54 & $3^{8}$ \\
\hline 7) Fairs and exhibits & 26 & 79 & 84 \\
\hline 8) Customers & 24 & 33 & 59 \\
\hline 9) Services of market research institutes & 18 & 42 & 37 \\
\hline
\end{tabular}

Source: For West Germany: Hüttner, M., Grundzüge der Marktforschung, Betriebswirtschaftlicher Verlag, Wiesbaden, r965, p. 292. For Hungary: Marketing Committee of the Hungarian Chamber of Commerce, 197r, unpublished material.

the potential results of the study; the scope of the work may be just an assessment of market potential, but the firm will expect precise guidelines for much of its production and marketing activities. Researchers at the institute must dispel this myth. In commissioning or soliciting work, personal contacts count a lot; more so than is the case in the West. But let there be no doubt; here too the customer must be satisfied, if he is to return. (Today in Hungary, as noted, he can choose among a variety of research institutes.)

In gathering the data, different sources of information will be utilized to a different extent in the East than in the West, as shown in Table 5. It is evident that Hungarian firms do not have access to, or do not use as intensively certain sources, even in I97I, as did West German organizations in 1962. But trade fair contacts, panels of both households and industrial experts, and in-store customers are reliable sources of market information in the socialist countries and, hence, are used extensively. International fairs have long occupied a major role; response rates from representative panels are very high $(80-90 \%)$; and buyers in stores are equally eager to co-operate. Personal and mail interviews are used much more than telephone surveys; sampling and questionnaire techniques follow universal procedures [26]. In Poland, advanced experimentation is taking place and their research methodology has been noted by Western observers [4].

The processing of information by mechanical and electronic means is not as advanced in the East as in the West. Hand tabulations are still frequent, calculations are also carried out "long hand". Access to computers or even calculators is rather limited; when available, the cost to the client may be prohibitive. While the number of computers is rising rapidly (from about 50 in 1967 to over 100 by 1970 in Hungary), most of them are used for internal data processing by large manufacturers or ministries.

In the text of the report, the analysis focuses on the economic and technical environment, and within that the potential for the products of the enterprise. Forecasting, which is one of the key tasks, is made easier by knowing the annual and five-year plans, the various targets and constraints and exportimport regulations. Because many firms are still production orientated, technical data and information on competitive materials are given more emphasis. 


\section{MARKET RESEARCH IN GUIDED MARKET PLACE}

than would be the case in a "Western report". Since foreign trade is an important factor and since the New Economic Mechanism encourages rivalry among enterprises, competition analysis, perhaps surprisingly, is given at least as much emphasis as one would expect by Western standards. Figures are broken down most frequently by demographic variables, economic sectors, or domestic vs. foreign markets. Expert opinions and results of panel surveys are given much weight. There is possibly too much use made of percentage distributions and trend calculations, and too little of such statistical procedures as chi-square analysis and analysis of variance.

In closing this section, we should comment on two interesting sidelights. First, the admittedly undesirable practice in the East of paying authors, aside from royalties, on the basis of the number of pages spread to commissioned material and, as a result, many market research reports tend to be lengthy. Clients are still impressed by weighty tomes; but a process of education and reform is under way and we expect that quantity of material will decline as quality rises. A second aspect of methodology is much more commendable. Many market researchers in Eastern Europe read one or more world languages (more so than the language of a neighbour state) and thus they are well aware of various Western publications in marketing.

\section{Case study no. 1: wine}

This was a study of production and consumption patterns and of the market potential for Hungarian wines at home and abroad. Published statistical and non-statistical sources for both Eastern and Western Europe were utilized; the field research in Hungary included interviews with 2000 households and 900 commercial units (restaurants, bars, grocery stores etc). There is much trans-shipment of wine among countries, but Hungary's export will continue to be distributed in a $4: 1$ ratio between socialist and nonsocialist countries. Co-operatives are producing a growing share of Hungary's wines; different winegrowing districts showed differential gains in pro- duction during the past decade. Consumption patterns are changing too; the Hungarian customer is now so affluent that he would rather pay a little more and get better quality wine. Certain brands have been gaining in the past decade and this trend is expected to continue. Bottled wine will grow at a faster rate than sale of wine in barrels or casks in taverns and taprooms. The income elasticity of wine is about 0.8 and the study concludes that growth in consumption is likely to remain modest, with beer and spirits showing better growth.

\section{Case study no. 2: women's underwear}

This was a primary survey conducted among three groups: representative households, head of clothing stores and customers in shops at the time of actual or potential purchase [28]. Information was collected on the level and composition of supply, consumer attitudes, buying habits, awareness of fashion trends, the role of advertising and publicity and the competition between domestic and foreign-made goods. Among the results were these:

I) about $90 \%$ of store managers appeared to be aware of the latest fashion trends;

2) fashion consciousness of customers drops sharply after age 30 and again after age 50 ;

3) for panties and nightrobes domestic makes are preferred over foreign ones by a 4 : I ratio, while just the reverse holds true for slips (although both types are available);

4) there are definite signs of unfilled demand, half of the customers having already looked for the item in question on a previous occasion;

5) knowledge of producers and brands was derived from a previous purchase for about half the customers, while for the other half, advertising, personal contacts and gifts represented the source of that knowledge.

\section{Case study no. 3 : cola drinks}

This is not really a case study, but the story of the successful entry of Western cola drinks into Hungary, without the benefit of much market research 


\section{MARKET RESEARCH IN GUIDED MARKET PLACE}

or advertising. Fruit drinks, espresso coffee, wine and beer have been traditional drinks in Hungary. While consumption has been rising for each of the above, certain "objections" do exist (eg fruit drinks are too sweet for some consumers; beer is fattening and alcoholic, etc). To "fill the gap" a drink named Vita cola, using base material from China, was introduced in the early r96os, but did not meet with acceptance. On the other hand, as a result of tourism and the impact of world-wide promotion, Western cola drinks were known but unavailable to Hungarians. Coca-Cola was introduced first, with manufacturing done under a licence as elsewhere. To encourage competition, Pepsi and other cola manufacturers were also given the right to enter the market.

Pepsi chose not to do any market research, testing or preliminary advertising. Rather, it began manufacturing and a "quiet distribution" to warehouses and stock rooms. Then it purchased all the available air time for commercials one evening (before news broadcast on television). It then informed the public of its entry into Hungary; guaranteed the quality of the product; and assured the audience that a wide distribution had been undertaken to grocery stores, canteens, restaurants, etc. Despite a great rush on outlets, a well-organized network of distribution continued to make Pepsi available "for the modern generation". Today, cola drinks are very popular with Hungarians, though of course they have not displaced the traditional strong coffee, beer or wines. Hungarian fruit drink manufacturers, however, are now undertaking a market research survey to compete better with the cola drinks.

\section{Case study no. 4 : passenger cars}

This market research study was commissioned by Merkur, the Hungarian state agency responsible for the sale and distribution of passenger cars; a summary of the findings was reported by the head of the organization in Marketing-Piackutatás [8]. Hungary makes no autos: all units must be imported from Comecon or Western nations, the former being preferred. Supply has been very limited and it is still not unusual to wait a year or more for certain models. But as of late, many more cars have become available and there is a flourishing used car market. Small, low-priced cars, with low operating costs appeal to and dominate the market. There is definite brand loyalty, based on a variety of factors. The study revealed several difficulties and dissatisfaction with distribution, servicing and parts supply at the time of purchase and thereafter. In addition to recommendations for alleviating this situation, the study estimated the existing stock of passenger cars in Hungary by a variety of methods, as shown in Figure 4. The booming car market has created a variety of satellite industries; service stations and repair shops are being opened in increasing numbers.

\section{Case study no. 5 : foreign markets}

This is a brief summary of how a state exportimport agency dealing with leather and related materials and fashion goods made from these looks at foreign markets. It sees its key tasks as assessing market potential, expanding sales and utilizing the advantages of the Hungarian labour market. Based on long-term trends and current statistics, as well as feedback from local representatives, it is able to judge in what countries Hungarian products have attained a minimum market penetration. Participation in fairs, regular survey of the press (including technical journals), and personal visits, are other key sources of information. Market research findings are coupled with national and organizational objectives (eg high labour content and high value added are desirable features for Hungarian exports at the moment), before formulating an overall marketing strategy.

\section{Case study no. 6 : vacation plans}

This study was commissioned by a branch of the Ministry of Commerce to ascertain the vacation plans and expenditures of Hungarians. (A similar study was made about foreign visitors.) With growing incomes and a rise in the number of resort 


\section{MARKET RESEARCH IN GUIDED MARKET PLACE}

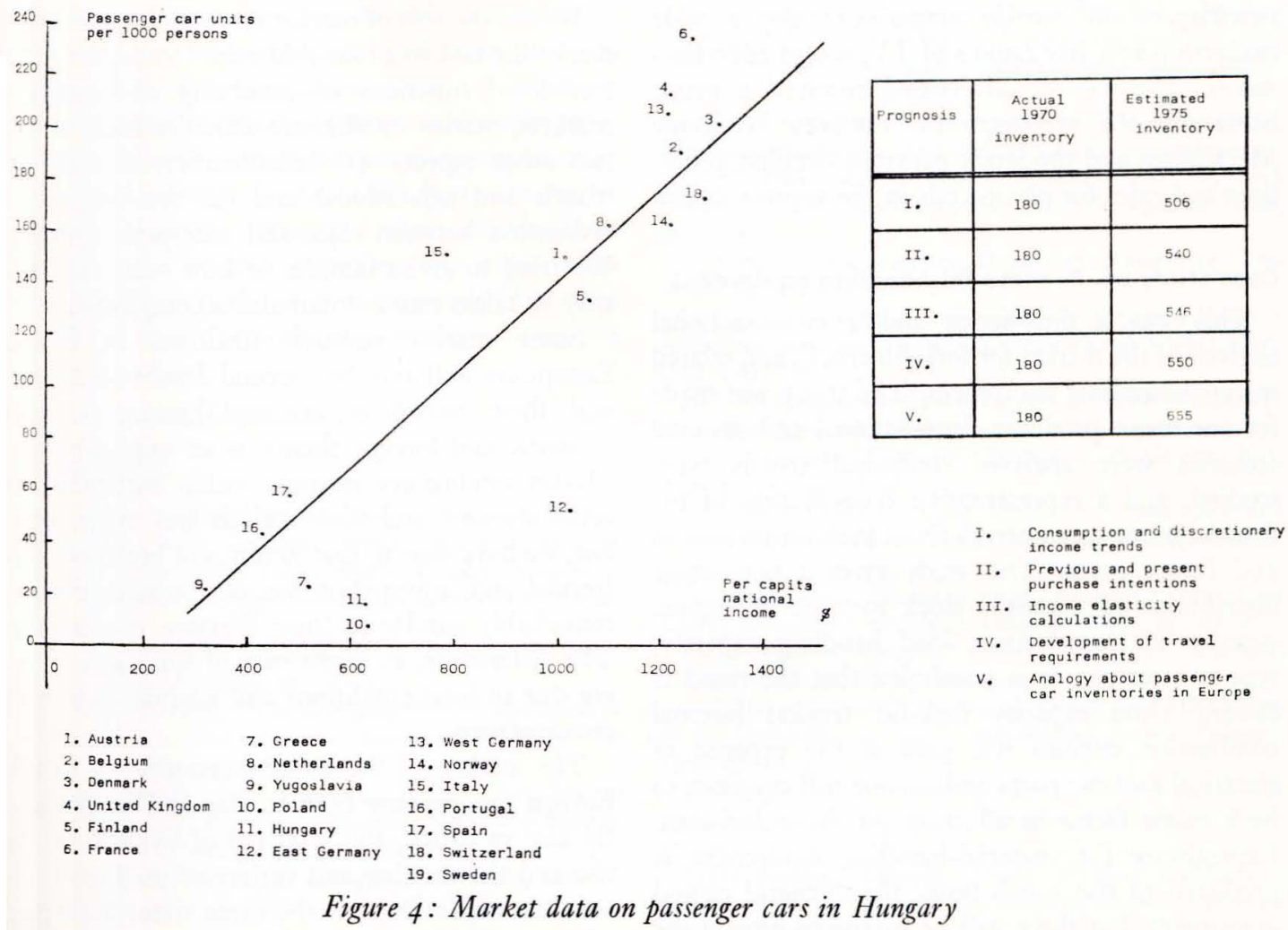

Source: Csüri, István, “The Expected Tendency of the Population's Demand for Private Cars”, Marketing-Piackutatás, Third Quarter, 1971, pp. 316-17.

spots, many Hungarians are now enjoying three weeks paid vacation. Still, about $35 \%$ of the population, mostly low income and non-urban residents, did not enjoy a holiday in the years immediately before the survey. Demographic variables affected both the length and the type of vacation taken, while ownership of a vacation home or a car influenced the destination of the journey and the distribution of expenditures. Lake Balaton continues to be the most popular spot, while very few go to Budapest for their holidays. Almost twothirds take their holidays in the third quarter of the year, with only $5 \%$ each opting for the first and fourth quarters. Thus, winter vacations are thought to be ripe for promotion, but only in terms of skiing and other winter sports, as a warm winter climate is unavailable in Hungary or even neighbouring countries.

\section{Case study no. 7 : advertising media}

This was a primary and secondary survey to ascertain the reading and viewing habits of the Hungarian audience and to summarize the availability of various advertising media for potential clients. This multi-client study proved to be popular among major and even intermediate size firms. Over $95 \%$ of Hungarian families have radios and almost the same percentage listen to radios each day. About three-quarters of the households now have television receivers (there is only one channel at present, but a second one is being added). Daily 


\section{MARKET RESEARCH IN GUIDED MARKET PLACE}

newspapers and weekly magazines enjoy a wide readership and, like radio and TV, accept advertisements. The role of advertising received a major boost after the introduction of the New Economic Mechanism and the study provides detailed guidelines and rates for placing ads in the various media.

\section{Case study no. 8 : material-handling equipment}

This was a time-series and a cross-sectional analysis of the market for fork-lift trucks and related material-handling equipment. The study was made for one major producer. International and national statistics were analysed, technical trends were studied, and a representative cross-section of industrial users were queried about their requirements and future plans. The study gives a percentage distribution of domestic stock by type of engine, country of manufacture, load handling capacity, type of user etc. It is concluded that the trend is toward I-ton capacity fork-lift trucks; internal combustion engines will gain at the expense of electrical motors; parts and service will continue to be a major factor in affecting purchase decisions. Expenditure for material-handling equipment is predicted to rise much faster than general capital investment, but there will be variations among the various sectors of the economy. The product line of the client is rated high among present and potential users and future market penetration both at home and abroad is judged to be favourable.

\section{SUMMARY AND CONCLUSIONS}

This article discussed various aspects of market research in Eastern Europe, with special regard to the Hungarian experience under the New Economic Mechanism. Previous publications, including those which appeared in the pages of this journal, focused on marketing activities; our topic was narrower, as we chose to emphasize market intelligence theory and practice. Marketing and, within it, market research are being given increasing attention in the socialist countries of Eastern Europe. This fact is of great interest to academicians, businessmen and government officials, both East and West.
We see the role of market research in the socialist marketing task in a four-fold way. In addition to the traditional functions of observing and analysing markets, market intelligence activities must include two other aspects: (I) consideration of social demands and aspirations; and (2) the task of coordination between state and enterprise planning. We tried to give examples of how such objectives may be taken into account and accomplished.

Some market research institutes in Eastern Europe are well into their second decade of existence and their record of accomplishment, for both domestic and foreign clients, is an impressive one. Market intelligence sections within enterprises are relatively new and their staff is less experienced; but, we have shown, that in terms of both tasks performed and information sources utilized, they are remarkably similar to their Western counterparts. The differences, as in the case of specific methods, are due to local conditions and adaptation to these circumstances.

The markets of the socialist countries of Eastern Europe are growing both in size and in diversity. By any yardstick, the standard of living is on the rise and the number and variety of products available are expanding. At the same time, buyers are more sophisticated and more discriminating. This poses a challenge to marketeers and, in turn, to market researchers. Several consumer information services aid both buyers and sellers in judging, respectively, the quality of the product and the reaction of the market.

In analysing East European markets, we attempted to show first the manner in which various sources of information can and should be utilized. There are specific advantages and disadvantages which must be kept in mind as one uses various publications and statistics. Next, we focused on methodology, and tried to highlight similarities and differences between East and West. Many techniques are identical, but generally they must be utilized in a "different mix". Finally, a typical cross-section of case studies was presented to illustrate the range of investigations and the depth of analysis undertaken. As seen, exploratory, descriptive and explanatory assign- 


\section{MARKET RESEARCH IN GUIDED MARKET PLACE}

ments are being carried out via field and desk research and both consumer and industrial products are being subjected to analysis.

It is impossible within the scope of a single paper to cover all facets of market research in the socialist countries of Eastern Europe. We hope the reader has gained some insights into organizations, methods and activities regarding this topic. Certainly, market research is an increasingly important function in these countries and promises to be one for years to come.

\section{REFERENCES}

[I] Kapferer, Clodwig, Market Research Methods in Europe, OEEC, Paris, 1956; German version: Marktforschung in Europa, B. Behr's Verlag GmbH, Hamburg, I963; Hungarian: Európai Piackutatás, Közgazdasági Jogi Könyvkiadó, Budapest, 1069 .

[2] Hurst, Ronald, "Marketing in Eastern Europe", Marketing, February I971, pp. 38-4r.

[3] Lauter, G. Peter, "The Changing Role of Marketing in the Eastern European Socialist Economies", fournal of Marketing, October 1971, pp. I6-20.

[4] Wills, Gordon and Hayhurst, Roy, "Marketing in Socialist Societies", British (now European) Fournal of Marketing, Vol. 5 No. I, Spring 1971, pp. 13-28.

[5] Hoványi, Gábor, “The Hungarian Marketing Scene", European Journal of Marketing, Vol. 5 No. 3, Autumn 1971, pp. $73-82$.

[6] Ravasz, Károly, "How to Make Known a Hungarian Company Abroad", Marketing-Piackutatás, Second Quarter I97I, pp. 133-8.

[7] Kelemen, Zoltán, "Methodology of Investigating Home Demand for New Equipment", Marketing-Piackutatás, Third Quarter I97r, pp. 303-I I.

[8] Csüri, Istvan, "The Expected Tendency of the Population's Demand for Private Cars", Marketing-Piackutatás, Third Quarter 197I, pp. 31 $5^{-20}$.

[0] Kornai, János, "Pressure and Suction on the Market", Közgazdasági Szemle, January I97I, pp. 4I-60.

[10] Gergely, István, "The Notion of Marketing and Its Socialist Application”, Közgazdasági Szemle, October 1971, pp. $1220-35$. [ri] Szabó, László, "Possibilities and Methods for Developing Market Research Relations Among the Socialist Countries", Marketing-Piackutatás, Fourth Quarter I97I, pp. 4054II.

[12] Gross, Andrew, "Market Research in North America", Marketing-Piackutatás, Second Quarter 1972 (forthcoming).

[13] Wilcsek, Jenö, "Market Research and Regulated Market”, Marketing-Piackutatás, Fourth Quarter I968, pp. 7-I2.

[14] Marketing Committee, Hungarian Chamber of Commerce, 1971, unpublished material.

[15] Exporting to the Socialist Countries of Eastern EuropeA Guide to Marketing Techniques, International Trade Centre, UNCTAD-GATT, Geneva, I97I.

[16] The Complex Program of the KGST (CMEA-Comecon), Kossuth Könyvkiadó, Budapest, I97I.

[17] "Summary Economic Outlook", Worldcasts, R-2, August I971, pp. I8-26.

[18] Éltető, Ödön and Láng, György, "Income Level and Income Stratification in Hungary", Közgazdasági Szemle, February I971, pp. I29-46.

[r9] Szita, János, "Equalizing the Economic Levels of the CMEA Countries", Gazdaság, December I97I, pp. 29-48.

[20] Hungarian Statistical Pocket Book, 1970, Statistical Publishing House, Budapest, 1970.

2I ] Major, Kálmán, "Purchasing Power and Cash Outlays of the Population in 1971", Kereskedelmi Szemle, February 1972, pp. 18-22.

[22] Gogol, B.I., "Studying Economic Information and Demand (in the USSR)", Marketing-Piackutatás, Third Quarter 1971, pp. 273-5.

[23] Galambos, Tiborné, "Some Practical Problems of Consumer Goods Import”, Kereskedelmi Szemle, September I97I, pp. II-I3.

[24] Bóc, Imre, "A Well Informed Consumer-A More Rational Purchasing", Marketing-Piackutatás, Fourth Quarter I97I, pp. 423-7.

[25] "Public Opinion Research on Commercial Policy", Marketing-Piackutatás, First Quarter I97I, pp. 5-12.

[26] Szabó, László, Vállalati Piackutatás, Managerial Market Research, Közgazdasági Jogi Könyvkiadó, Budapest, I969.

[27] Miracle, G.E. and Albaum, G.S., International Marketing Management, R.D. Irwin Inc., Homewood, Ill., 1970, chapters 9 and ro.

[28] Medgyessy, Ildikó, "Demoscopic Investigations into Women's Underwear Market”, Marketing-Piackulatás, First Quarter 1971, pp. 19-24. 